\title{
The effects of crude extract of Amaranthus hybridus (000059604) on reproductive parameters of the male Wistar rats
}

$*^{1}$ Oyeyemi, M. O., ${ }^{2}$ Adedeji, V. B. and ${ }^{3}$ Bankole, A. M.

Department of Theriogenology,

Faculty of Veterinary Medicine

University of Ibadan, Nigeria

\begin{abstract}
* Corresponding author: momattyemi@gmail.com

Studies on Amaranthus hybridus (AH) have established its antioxidant properties. This study investigated the effects of AH on some reproductive parameters offorty-five sexually matured Albino rats (Wistar Strain) males. Amaranthus hybridus has been reported to have several protective and curative properties attributed majorly to strong antioxidant activity. They were randomly grouped into 3 with each group consisting of 15 rats. Group A received (per Os) Amaranthus hybridus (50mg/kg body weight) and group B had Amaranthus hybridus $(100 \mathrm{mg} / \mathrm{kg}$ body weight for 7 days. Group $C$ (control) received distilled water for 7 days. Blood and semen samples were collected for analyses on day 1,8,15 and 22 post-treatments.

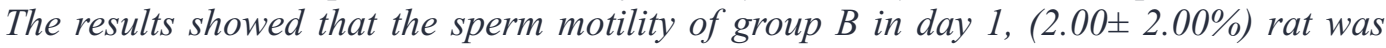
significantly lower $(p<0.001)$ than that of group $C(26.00 \pm 7.97 \%)$, whereas it was greatly improved in Group B $(85.00 \pm 4.47 \%)$ and Group $A(60.00 \pm 4.47 \%)$ at the day 22 posttreatment. Livability of sperm cells were significantly higher $(p<0.50)$ in Group $A$

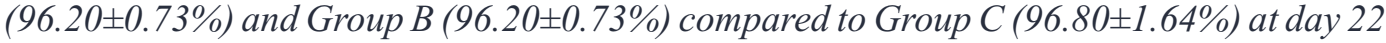
post-treatment. The histology of the testis of control and all treatment groups revealed normal testicular germinal epithelium full of viable spermatogenic cells. It is, therefore, concluded that Amaranthus hybridus extract given orally at $50 \mathrm{mg} / \mathrm{kg}$ and $100 \mathrm{mg} / \mathrm{kg}$ body weight, did not affect the normal cytoarchitecture of the testis and epididymis and can increase sperm production.
\end{abstract}

Keywords: Wistar Rat, Semen, Epididymides, Amaranthus hybridus, histomophometry, testis

\section{Introduction}

Most developing countries depend on starch-based food as the main staple food for the supply of both energy and protein. This accounts in part for protein deficiency which prevails among the populace as recognized by Food and Agricultural organization FAO (Ladeji et al.,1995). Vegetables are the cheapest and most readily available sources of important vitamins, minerals, proteins and essential amino acids (Okafor,1983). Inadequate scientific knowledge of the nutritional potential of many of the local vegetables has made them underexploited (Akubugwo, 2007). However, many researchers (Hassan and Umar, 2006, Ekop, 2007) have reported the compositional evaluation and functional properties of different plants. As a result of this, more than $50 \%$ of modern drugs used clinically are of natural product origin and therefore play an important role in the drug development programmes (Lieber, 1997).

The whole plant of $\mathrm{AH}$ which consists of the leaves, stem and roots together with the seeds are of great importance. The Kerala tribe uses the juice of $\mathrm{AH}$ to prevent swellings around the stomach. The leaves, when boiled without salt and consumed for 2-3 days, is used in curing jaundice and can also serve as a cure to certain rheumatic and stomach pain. The leaves together with the roots are applied as a poultice to relieve wounds, burn, bruises and inflammation. Besides, when the roots and leaves are 


\section{Crude extract of Amaranthus hybridus and reproductive parameters of Wistar rats}

boiled, it serves as a laxative when given to children. The root paste in an equal volume of honey is used to control vomiting. The whole plant also serves as an antidote against snake venom (Kirtikar and Basu, 2001). Amaranthus hybridus has been documented to be used traditionally by the Msambweni community of Kenya South coast (where malaria is endemic) to treat malaria (Ngita et al., 2010)

The presence of antioxidant defense factors such as flavonoids like alpha-tipoic acid and phenolic compounds in Amaranthus hybridus is useful against foreign bodies. Phenols contribute to the flavour, colour and astringency of plants in addition to the free radical scavenging properties (Frankel et al., 1993). This potentially benefits human health by reducing the occurrence of coronary heart disease and age-related atherogenic processes (Hoffman, 1997). Alphatipoic acid has shown an increase in insulin sensitivity whereby lowering glucose levels and preventing oxidative stress-induced changes in patients with diabetes. It is important to note that most studies have used intravenous alpha-lipoic acid and it is unsure whether oral supplementation would elicit the same benefits (Ngita et al., 2010). Studies by Joshua et al. (2010) revealed that Amaranthus hybridus is very aggressive against prostate cancer and has been linked to epoxanthophylls, neoxanthin and violaxanthin which are carotenoids that directly reduce tumorous activity and spread of cancer throughout the body. Amaranthus hybridus is recommended to those with high blood pressure to negate the effect of sodium in the body. The sodium/potassium ratio in the body is of great concern for the prevention of high blood pressure. A ratio of less than one (1) is recommended. Amaranthus hybridus would probably reduce high blood pressure because its sodium/potassium ratio is less than one (1) (Turan et al., 2006). When compared with omeprazole, leaves of Amaranthus hybridus elicited anti peptic ulcer activity against ethanol and cysteamine but relatively less than omeprazole (Ghosh et al., 2016). The study has documented Amaranthus spp. given to Plasmodium berghei infected mice to show a gain or increase in body weight, increased haemoglobin content and blood schizonticidal activity, exerting an antimalarial effect comparable to chloroquine (Susantiningsih et al., 2012). In reproduction of Wistar rats, the penis is flexed posteriorly with the glands lying within a non-protruding prepuce, also present are low epididymal papillae on the glands. In most species, a pair of welldeveloped preputial glans lies between the skin and ventral body wall and lateral to the penis, however, absent in gerbil. In each species, there is a pair of large seminal vesicle consisting of sactike structures which are flexed ventrally at the anterior end. Hafez (1970) reported that also present is an ampullary gland from two distinct lobes (each arising from each of the ductus deferens). The prostate gland is well developed and consists of three pairs of lobes; the anterior lobe is known as 'the coagulating' gland, and it lies along and attached to the ventral curvature of the seminal vesicle. A urethral sinus which consists of a bulb-tike diverticulum of the membranous urethra is located proximal to the bulb of the penis. This is surrounded by the musculature of the urethral glands in the wall of the sinus extending down to the penile urethra in the hamster; but in other species, they are reported to terminate at the end of the sinus. Paired bulbourethral glands are located dorsolateral to the bulb of the penis (Eckstein and Zuckerman, 1965). Therefore, this research is designed to evaluate the effects of the crude extract of Amaranthus hybridus on some reproductive indices of the male Wistar rats 


\section{Oyeyemi, Adedeji and Bankole}

\section{Materials and methods Location of study}

The study was carried out at the Experimental Animal Unit of the Faculty of Veterinary Medicine University of Ibadan. University of Ibadan, Oyo State is about $6 \mathrm{~km}$ North of Ibadan city at latitude $2^{\circ}$, longitude $3^{\circ} 54^{1}$ east at mean attitude of $277 \mathrm{~m}$ above sea level. The annual rainfall is $1200 \mathrm{~mm}$ most of which fall between April and November, and a dry season from December to March (Oyeyemi and Fayomi, 2011).

\section{Experimental animals}

Forty-five male Wistar rats of average body weight between $110 \mathrm{~g}-130 \mathrm{~g}$ and about 100 days old were purchased and housed in rectangular metallic cages under 12 hours light and 12 hours darkness in Experimental Animal Unit of the Faculty of Veterinary Medicine. They were left to acclimatize for 7 days where necessary veterinary attentions were given. The rats were randomly divided into three groups each containing 15 rats $(n=15)$. The rats were housed in rectangular metallic/plastic cages which measure about $420 \mathrm{~m}$ in diameter, depth of $10 \mathrm{~cm}$ with a wooden and wire meshed roof and each box contained fifteen rats. The rats were fed on a commercial rat feed having a composition of $21 \%$ protein, $3.5 \%$ fat, $6 \%$ fibre and $0.8 \%$ phosphorus. Freshwater was administered to the rats ad libitum.

\section{Plant materials}

Freshly harvested Amaranthus hybridus were purchased from a local market in Ibadan. The fleshy leaves were picked, and the roots removed. The leaves were rinsed with tap water several times and finally rinsed with deionized distilled water. The leaves were separated and chopped into small pieces and kept under an electric fan at room temperature in a well-ventilated room for 2 weeks. The leaves were air-dried and $840 \mathrm{gm}$ of the dried leaves was obtained after blending. The blended leaves of
Amaranthus hybridus was transferred into a glass container and $5 \mathrm{ml}$ of distilled water. The mixture was stirred every 2 hours for 24hours after which the product (filtrate) was collected in a muslin bag for sieving. The filtrate was separated from the shaft using Whatman's filter paper. The filtrate was then concentrated using Rotary evaporator (RE52-2 Search Technological instrument) set at $40^{\circ} \mathrm{C}$. The concentration was further increased with the use of a vacuum oven set at $45^{\circ} \mathrm{C}$ and pressure of $700 \mathrm{mmHg}$. The concentrated aqueous extract was then weighed, and the percentage yield calculated and stored in a sterile airtight container at $4^{\circ} \mathrm{C}$ until future use. The rats were divided into 3 groups $\mathrm{A}$, $\mathrm{B}, \mathrm{C}$ with 15 rats each. Group A rats were treated with $50 \mathrm{mg} / \mathrm{kg}$ bodyweight of a crude spinach extract. Group B rats were treated with $100 \mathrm{mg} / \mathrm{kg}$ bodyweight of crude spinach extract which was previously documented by (Islam, 2009). Group C rats were administered distilled water. The duration for the oral administration was seven days. The groups were kept under the same temperature and relative humidity. The dosage of the extract administered was based on the average body weight of the rat $(120 \mathrm{~g})$. Each rat received $0.2 \mathrm{ml}$ dosing while the treatments were administered using an oral cannula daily. At the end of the treatment, the rats were sacrificed by cervical dislocation. The right testis and cauda epididymis of the animals were dissected, and the testis was cleared from fat tissue.

\section{Blood collection}

At the end of the treatment, a blood sample from the orbital sinus of each rat by the infraorbital media canthus method was collected into well-labelled heparinised sample bottles for haematology. The analysis of blood sample to determine the packed cell volume (PCV), red blood cell count, white blood cell count, differential lymphocytes count, and differential 


\section{Crude extract of Amaranthus hybridus and reproductive parameters of Wistar rats}

neutrophil count were carried out as described by Reece (1997).

\section{Semen collection}

The testicles were removed from the scrotal sacs immediately after the animals were euthanized by cervical dislocation to prevent the death of the spermatozoa.

The sperm cells were harvested on days 1 , 8,15 and 22 from the cauda epididymis which was slightly cut with a clean sterile razor blade and gently placed on a clean warm glass slide and semen characteristics and morphology was determined method described by Zemjanis, (1970) and Oyeyemi and Ubiogoro, (2005)

\section{Histomorphometry}

The prepared slides from the testes and epididymis were examined under the microscope and the following measurements were taken; the relative depth of the germinal epithelium, interstitium and lumen of the seminiferous tubules and the seminiferous tubular diameter. For each parameter, ten measurements were made per section using a TS view (C) software (China). (Olukole and Obayemi, 2010).

\section{Statistical analysis}

Descriptive and inferential statistical methods were employed to analyze the data. Descriptive analyses included means and standard error as well as bar charts. Being a simple one-way randomized control experiment, one-way analysis of variance (ANOVA) was used to compare mean values across the experimental groups. Turkey's Honestly Significantly Difference (HSD) Test was used for posthoc pair comparison. The inferential statistics were conducted at 5\% significant level. Data management and analyses were done with Microsoft Office Excel 2016 (Microsoft ${ }^{\circledR}$ Corporation, 2016) and IBM SPSS Statistics Version 22 (IBM Corporation, 2013).

\section{Results}

The sperm motility values (Figure 1) were significantly different $(\mathrm{p}<0.05)$ across the three groups for the three batches of posttreatment. The batch of the test groups from day 1 post-treatment had the least score of sperm motility and this was statistically significant when compared to other groups. Percentage motility increases as post treatment day increases and dose $100 \mathrm{mg} / \mathrm{kg}$ at day 22 value was higher than the control value.

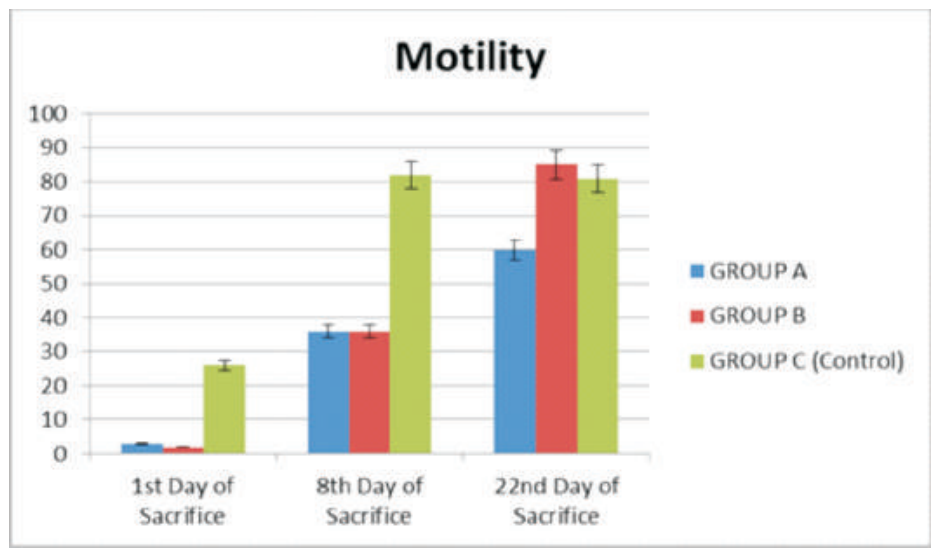

Figure 1: Comparison of percentage mean values (+SEM) of sperm motility across the groups 


\section{Oyeyemi, Adedeji and Bankole}

The percentage livability in Figure 2 shows no significant difference between all the groups. It also shows progressive increase in the percentage of livability. It gives the best result and equal to the control group at day 22 .

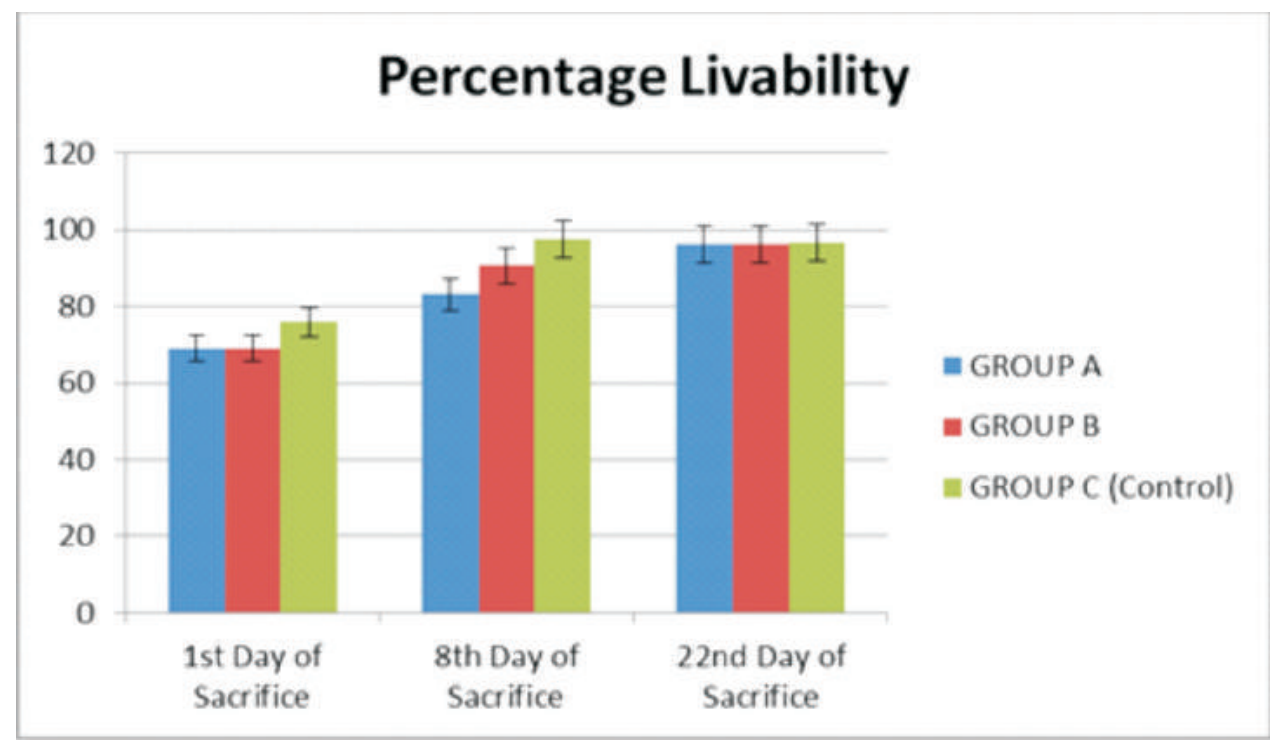

Figure 2: Comparison of percentage mean values (+SEM) of livability across the groups

Higher mean percentage abnormalities in sperm cells (fig. 3 ) were observed in the $8^{\text {th }}$ day post-treatment batch of animals dosed with $100 \mathrm{mg} / \mathrm{kg}$ of crude AH extract. These percentages were statistically significant $(p<0.05)$ when compared to controls of the first (1) day and $22^{\text {nd }}$ day post treatment but this value reduced at day 22 lower than group A. these values are less that maximum of $20 \%$ allowed.

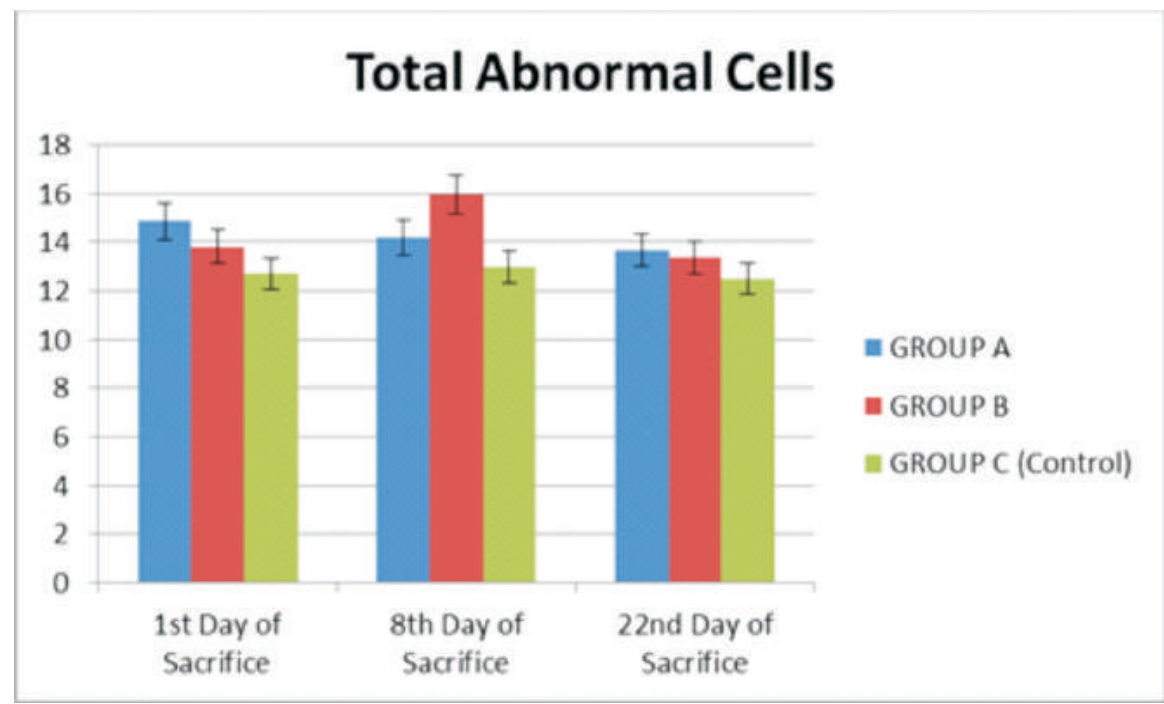

Figure 3: Comparison of percentage mean values (+SEM) of total abnormal sperm cells across the groups 
The haematology profile in Table 1 shows that there was a significant increase $(\mathrm{p}<$ 0.05 ) in the platelets value of group A and B rats treated with $50 \mathrm{mg} / \mathrm{kg}$ and $100 \mathrm{mg} / \mathrm{kg}$ $\mathrm{AH}$ extract respectively compared to the control with group A having the highest value $(135600 \mathrm{ml})$. All other blood parameters were within the normal range and there were no significant $(\mathrm{p}>0.05)$ changes in their mean values across the groups.

Table 1: Haematological profile of Wistar albino rats day 1 post-treatment

\begin{tabular}{|c|c|c|c|c|c|}
\hline \multicolumn{6}{|c|}{ GROUP } \\
\hline Parameters & $\mathrm{A}(50 \mathrm{mg} / \mathrm{kg})$ & B (100mg/kg) & $\mathrm{C}$ (control) & F & P-Value \\
\hline PCV \% & $50.20 \pm 2.85$ & $50.80 \pm 4.47$ & $53.40 \pm 2.52$ & 0.252 & 0.781 \\
\hline $\mathrm{HB} \mathrm{g} / \mathrm{dL}$ & $16.40 \pm 0.93$ & $16.20 \pm 1.35$ & $17.16 \pm 0.59$ & 0.253 & 0.781 \\
\hline Red blood cells $/ \mathrm{mm}^{3}$ & $8.15 \pm 0.47$ & $6.95 \pm \pm 1.74$ & $8.52 \pm 0.31$ & 0.611 & 0.559 \\
\hline White blood cells $/ \mathrm{mm}^{3}$ & $6660.00 \pm 275.41$ & $5630.00 \pm 367.97$ & $5910.00 \pm 220.45$ & 3.275 & 0.073 \\
\hline Platelets (uL) & $135600.00 \pm 6201.61^{\mathrm{a}}$ & $127000.00 \pm 5856.62^{\mathrm{ab}}$ & $96200.00 \pm 3611.09^{c}$ & 15.006 & $0.001^{*}$ \\
\hline Lymphocytes $/ \mathrm{mm}^{3}$ & $4435.90 \pm 203.03$ & $3723.30 \pm 295.94$ & $3833.80 \pm 263.53$ & 2.226 & 0.151 \\
\hline Neutroophils $/ \mathrm{mm}^{3}$ & $1987.30 \pm 124.58$ & $1687.10 \pm 108.07$ & $1923.60 \pm 90.36$ & 2.214 & 0.152 \\
\hline Monocyte cell/uL & $105.50 \pm 16.64$ & $117.60 \pm 17.52$ & $82.40 \pm 14.12$ & 1.278 & 0.314 \\
\hline Eosinophil mm $\mathrm{mm}^{3}$ & $131.30 \pm 28.07$ & $104.20 \pm 25.04$ & $70.20 \pm 20.79$ & 1.522 & 0.257 \\
\hline MCV(pg/cell) & $61.63 \pm 0.68$ & $63.04 \pm 0.65$ & $62.59 \pm 1.22$ & 0.653 & 0.538 \\
\hline $\mathrm{MCH}(\mathrm{g} / \mathrm{dL})$ & $32.67 \pm 0.19$ & $31.96 \pm 0.22$ & $32.31 \pm 0.44$ & 1.397 & 0.285 \\
\hline $\mathrm{MCH}$ (pg/cell) & $20.13 \pm 0.11$ & $20.14 \pm 0.11$ & $20.14 \pm 0.09$ & 0.001 & 0.99 \\
\hline
\end{tabular}

Values are reported as mean \pm SEM

*Significant at $(\mathrm{p}<0.05)$

abc: Means in the same row with different superscript differ significantly $(\mathrm{P}<0.05)$.

$\mathrm{MCV}-\mathrm{Mean}$ cell volume

$\mathrm{MCH}-\mathrm{Mean}$ cell haemoglobin

$\mathrm{MCHC}$ - Mean cell haemoglobin concetration

The mean haematological values of rats at 8 days post-treatment with crude extract of AH (Table 2). There were no observable significant changes $(p>0.05)$ in the parameters taken except for $\mathrm{MCH}$ which is slightly increased in group A $(20.97 \pm 0.05)$ and $\mathrm{B}(20.35 \pm 0.22)$ compared to the control group $\mathrm{C}(20.41 \pm 0.15)$. All the blood parameters were within the normal range.

Table 3 expressed the mean values of the blood parameters of the rats in group A, B and $\mathrm{C}$ at $22^{\text {nd }}$ day post-treatment. There were no observable significant $(p>0.05)$ changes in the mean values across the groups and all the values fall with the normal range in rats.

Plate 1 shows Light micrograph of the rat

testis day 1 post-treatment. A: group treated with $50 \mathrm{mg} / \mathrm{kg}$ of Amaranthus hybridus crude extract (AHCE). B: group treated with $100 \mathrm{mg} / \mathrm{kg}$ of (AHCE) C: (control) group treated with distilled water only. A, B and $\mathrm{C}$ had no visible lesions in the epithelium (arrowed) H\&E, Mag. X400

Testicular micrograph of the treated groups showing normal cytoarchitecture of the germinal epithelium, Sertoli cells, intact basement membrane and interstitial Leydig cells in group A and group B similar to what we have in the control group revealing an evidence of spermatogenesis.

Histology of testis revealed numerous, large seminiferous tubules (arrow) packed with spermatogenic cells. Cytoarchitecture of the testis appears normal. 
Oyeyemi, Adedeji and Bankole

Table 2: Haematological profile of Wistar strain albino rats day 8 post-treatment

\begin{tabular}{|c|c|c|c|c|c|}
\hline \multirow[b]{2}{*}{ Parameters } & \multicolumn{3}{|c|}{ GROUP } & \multirow[b]{2}{*}{$\mathbf{F}$} & \multirow[b]{2}{*}{ P-Value } \\
\hline & $\mathrm{A}(50 \mathrm{mg} / \mathrm{kg})$ & B (100mg/kg) & $\mathrm{C}$ (control) & & \\
\hline PCV \% & $39.80 \pm 0.37$ & $39.60 \pm 1.03$ & $39.80 \pm 0.49$ & 0.028 & 0.973 \\
\hline $\mathrm{HB} g / \mathrm{dL}$ & $13.50 \pm 0.04$ & $13.42 \pm 0.37$ & $13.44 \pm 0.19$ & 0.03 & 0.97 \\
\hline $\begin{array}{l}\text { Red blood cells } \\
/ \mathrm{mm}^{3}\end{array}$ & $6.44 \pm 0.03$ & $6.59 \pm 0.17$ & $6.58 \pm 0.07$ & 0.663 & 0.533 \\
\hline $\begin{array}{l}\text { White blood cells } \\
/ \mathrm{mm}^{3}\end{array}$ & $4770.00 \pm 597.41$ & $4610.00 \pm 328.79$ & $6490.00 \pm 1145.91$ & 1.833 & 0.202 \\
\hline Platelets (/uL) & $158800.00 \pm 40829.40$ & $177400.00 \pm 18701.87$ & $187200.00 \pm 15041.28$ & 0.278 & 0.762 \\
\hline $\begin{array}{l}\text { Lymphocytes/ } \\
\mathrm{mm}^{3}\end{array}$ & $2947.90 \pm 404.45$ & $2823.20 \pm 193.30$ & $4465.10 \pm 836.41$ & 2.784 & 0.102 \\
\hline $\begin{array}{l}\text { Neutroophils } \\
/ \mathrm{mm}^{3}\end{array}$ & $1630.10 \pm 210.1$ & $1617.50 \pm 180.85$ & $1822.90 \pm 353.86$ & 0.197 & 0.824 \\
\hline Monocyte $/ \mathrm{mm}^{3}$ & $92.90 \pm 16.29$ & $73.00 \pm 11.41$ & $106.50 \pm 27.69$ & 0.732 & 0.501 \\
\hline Eosinophil $/ \mathrm{mm}^{3}$ & $99.10 \pm 22.68$ & $89.00 \pm 29.51$ & $95.50 \pm 32.31$ & 0.032 & 0.968 \\
\hline MCV (pg/cell) & $61.69 \pm 0.47$ & $60.07 \pm 0.86$ & $60.44 \pm 0.33$ & 1.997 & 0.178 \\
\hline $\operatorname{MCHC}(\mathrm{g} / \mathrm{dL})$ & $33.93 \pm 0.27$ & $33.88 \pm 0.27$ & $33.77 \pm 0.16$ & 0.125 & 0.884 \\
\hline $\mathrm{MCH}(\mathrm{pg} / \mathrm{cell})$ & $20.97 \pm 0.05 \mathrm{a}$ & $20.35 \pm 0.22 b$ & $20.41 \pm 0.15 \mathrm{ac}$ & 4.968 & $0.027^{*}$ \\
\hline $\begin{array}{l}\text { Values are re } \\
\text { *Significant } \\
\text { abc: Means in } \\
\text { MCV-Mear } \\
\text { MCH-Mean } \\
\text { MCHC-Me }\end{array}$ & $\begin{array}{l}\text { orted as mean } \pm \text { SEM } \\
\text { it }(\mathrm{p}<0.05) \\
\text { the same row with dif } \\
\text { cell volume } \\
\text { cell haemoglobin } \\
\text { an cell haemoglobin c }\end{array}$ & nt superscript diffe & nificantly $(\mathrm{P}<0.05)$ & & \\
\hline
\end{tabular}

Table 3: Haematological Profile of Wistar Strain Albino rats for day 22 post-treatment

\begin{tabular}{|c|c|c|c|c|c|}
\hline \multirow[b]{2}{*}{ Parameters } & \multicolumn{3}{|c|}{ GROUP } & \multirow[b]{2}{*}{ F } & \multirow[b]{2}{*}{ P-Value } \\
\hline & $\mathrm{A}(50 \mathrm{mg} / \mathrm{kg})$ & B (100mg/kg) & $\mathrm{C}$ (control) & & \\
\hline PCV \% & $39.80 \pm 1.24$ & $39.00 \pm 1.22$ & $39.60 \pm 1.50$ & 1.57 & 0.248 \\
\hline $\mathrm{HB}(\mathrm{g} / \mathrm{dl})$ & $13.44 \pm 0.42$ & $12.88 \pm 0.52$ & $12.38 \pm 0.47$ & 1.264 & 0.318 \\
\hline Red blood cells $\mathrm{mm}^{3}$ & $6.74 \pm 0.21$ & $6.51 \pm 0.28$ & $6.02 \pm 0.27$ & 2.088 & 0.167 \\
\hline White blood cells $\mathrm{mm}^{3}$ & $5030.00 \pm 794.13$ & $6110.00 \pm 868.25$ & $6576.00 \pm 1444.65$ & 0.544 & 0.594 \\
\hline Platelets( ml) & $123800.00 \pm 16731.40$ & $104600.00 \pm 8885.94$ & $112800.00 \pm 9931.77$ & 0.609 & 0.56 \\
\hline Lymphocytes $\mathrm{mm}^{3}$ & $3197.00 \pm 428.31$ & $3613.20 \pm 448.93$ & $4250.28 \pm 1027.75$ & 0.586 & 0.572 \\
\hline Neutroophils $\mathrm{mm}^{3}$ & $1516.70 \pm 260.92$ & $2283.00 \pm 421.55$ & $2134.48 \pm 438.64$ & 1.131 & 0.355 \\
\hline Monocyte $\mathrm{mm}^{3}$ & $79.30 \pm 18.88$ & $315.20 \pm 159.28$ & $107.76 \pm 24.84$ & 1.888 & 0.194 \\
\hline Eosinophil mm $\mathrm{m}^{3}$ & $84.00 \pm 16.93$ & $68.70 \pm 24.36$ & $74.08 \pm 18.91$ & 0.146 & 0.866 \\
\hline MCV(fl) & $59.08 \pm 0.77$ & $60.05 \pm 0.98$ & $60.82 \pm 0.52$ & 1.256 & 0.32 \\
\hline $\mathrm{MCHC} \%$ & $33.48 \pm 0.16$ & $33.49 \pm 0.63$ & $33.45 \pm 0.39$ & 0.002 & 0.998 \\
\hline $\mathrm{MCH}(\mathrm{pg})$ & $19.76 \pm 0.51$ & $19.81 \pm 0.34$ & $20.83 \pm 0.31$ & 1.381 & 0.288 \\
\hline
\end{tabular}

Values are reported as mean \pm SEM

Significant at $(p<0.05)$ 

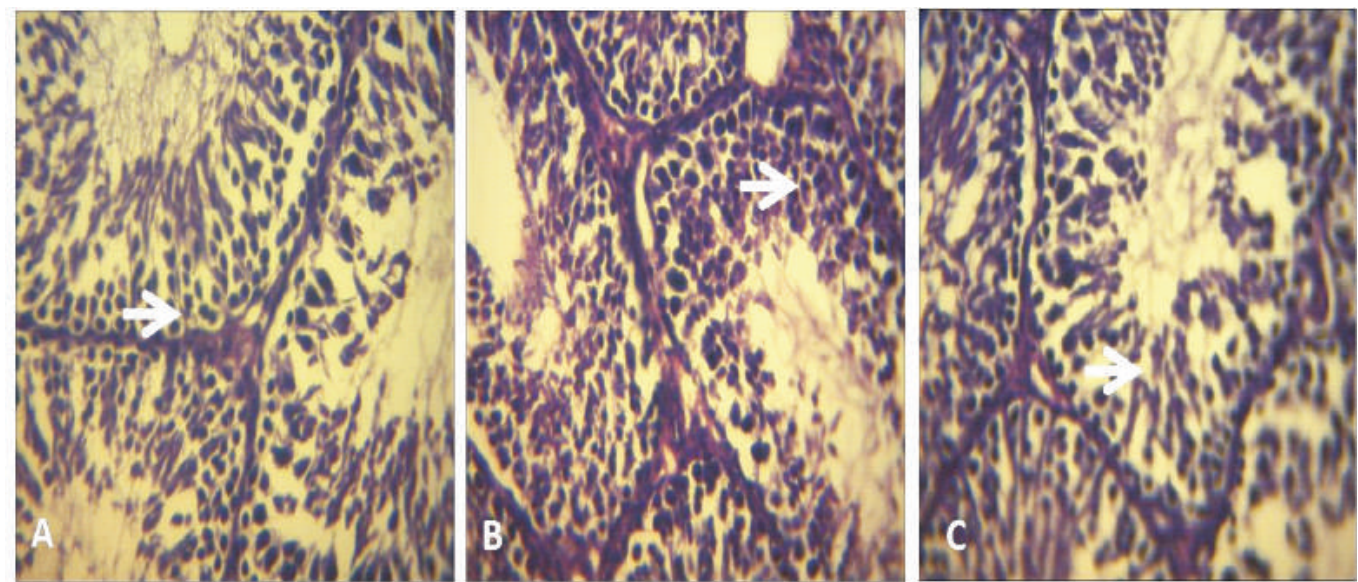

Plate 1: Histology of testis and epididymis

Plate 2 shows light micrograph of the rat epididymis at day 22 post-treatment with Amaranthus hybridus crude extract (AHCE). A group treated with $50 \mathrm{mg} / \mathrm{kg}$ of AHCE. B: group treated with $100 \mathrm{mg} / \mathrm{kg}$ of AHCE C: (control) group treated with distilled water only. $\mathrm{A}, \mathrm{B}$ and $\mathrm{C}$ had no visible lesions in the epithelium (arrowed) H\&E, Mag. X400

The epididymis contained moderate number of spermatozoa with well-defined germinal epithelial layer. Cytoarchitecture show no lesions.

Epididymal luminar diameter of group A $(111.81 \pm 17.93)$ and group B $(73.30 \pm 8.90)$ was statistically different from group $\mathrm{C}$ $(54.48 \pm 9.58)$ at the first day post treatment. In addition, the epididymal germinal height also revealed a statistically significant difference $(p<0.05)$ among the treatment groups A (15.56 \pm 1.35$)$ and B $(15.08 \pm 1.50)$ when compared to the control $(9.51 \pm 1.11)$ at day 1 post-treatment
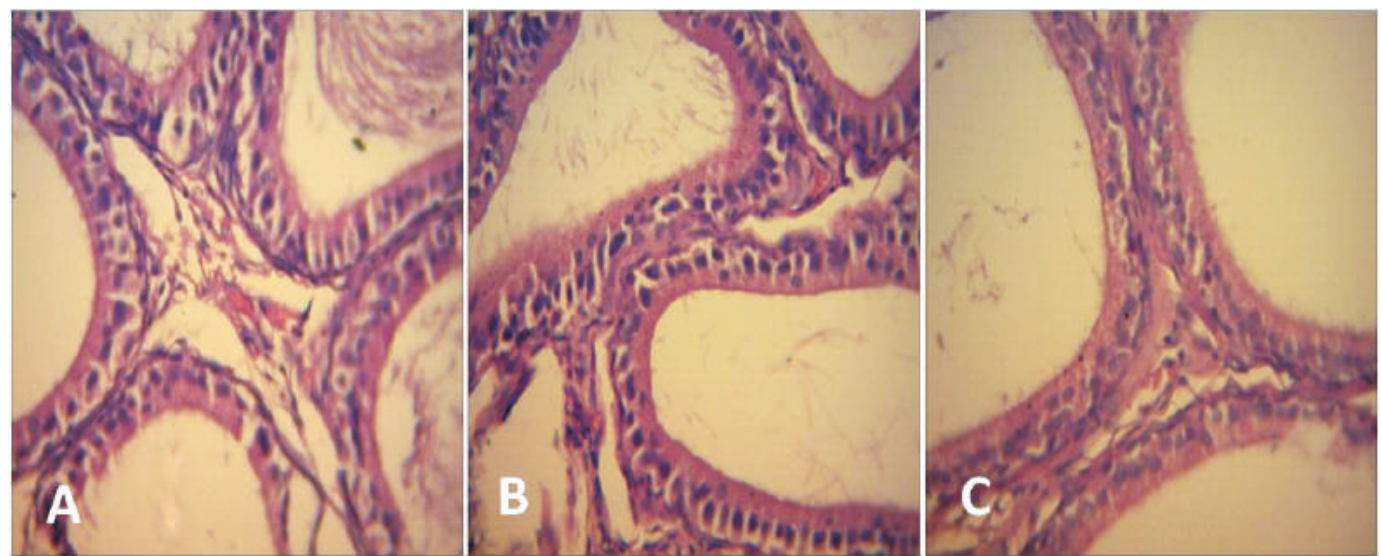

Plate 2: Light micrograph of the rat epididymis at day 22 post-treatment

\section{Histomorphometry}

A statistically significant difference was observed at day 8 post-treatment with the histomorphometric testicular germinal height of the treatment group A $(49.73 \pm 4.70)$ and $B(50.81 \pm 5.12)$ when compared with the control $(26.77 \pm 3.64)$. The epididymal epithelial height also 
follow the same trend with a statistically significant difference $(\mathrm{p}<0.05)$, group A (106.56 \pm 9.65$)$, group B $(55.87 \pm 7.39)$ and Group C; Control (16.46 \pm 1.37$)$. At day 22 post-treatment, the mean value of epididymal luminal diameter in group C; control $(16.46 \pm 1.37)$ showed a statistically significant difference $(\mathrm{p}<0.05)$ from the treatment group A $(106.56 \pm 9.65)$ and group B (55.87 \pm 7.39$)$, respectively. Also, the mean epididymal epithelial height was observed to have a statistically significant difference between the treatment groups A $(24.71 \pm 1.84), \mathrm{B}(15.29 \pm 1.29)$ and the control group C $(2.22 \pm 0.13)$.

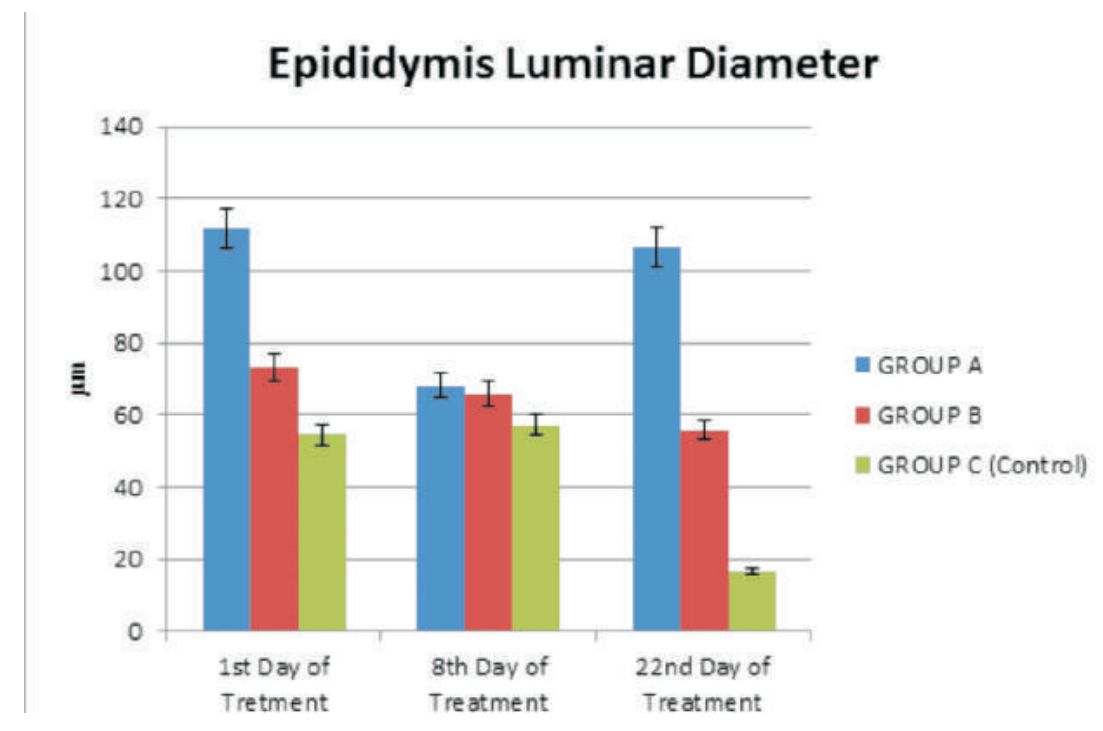

Fig. 4. Bar chart comparing the mean differences in the epididymal luminar diameter across the groups

Histomorphometrical measurement of the cauda epididymis (Fig. 6 and 7) revealed the significant difference $(\mathrm{p}<0.05)$ in the epididymal luminar diameter and the epididymal germinal height among and across the three groups.

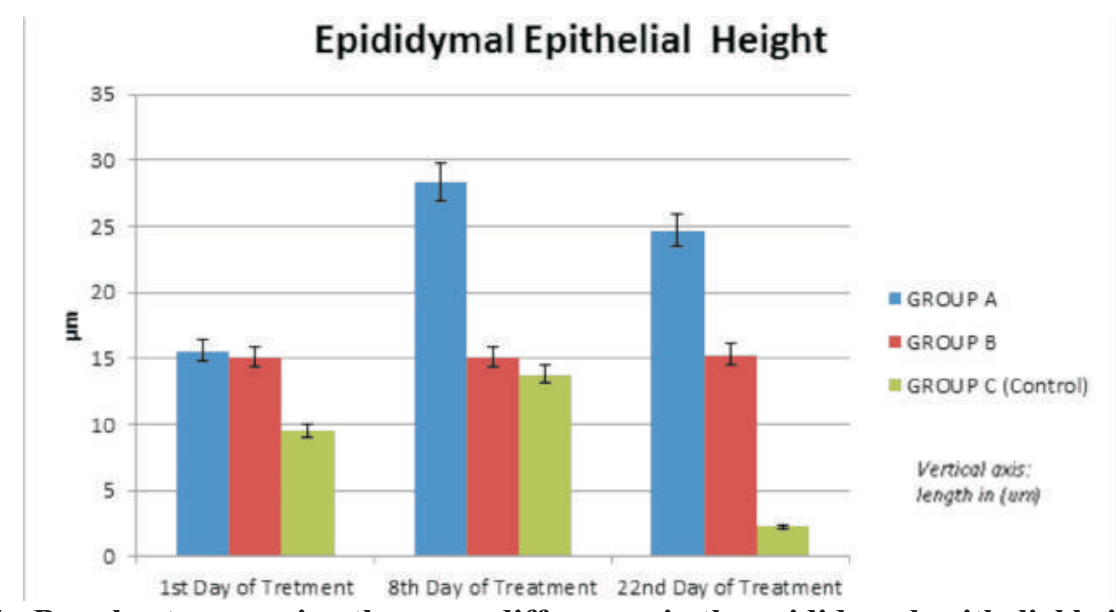

Figure 5: Bar chart comparing the mean differences in the epididymal epithelial height across the groups 
Crude extract of Amaranthus hybridus and reproductive parameters of Wistar rats

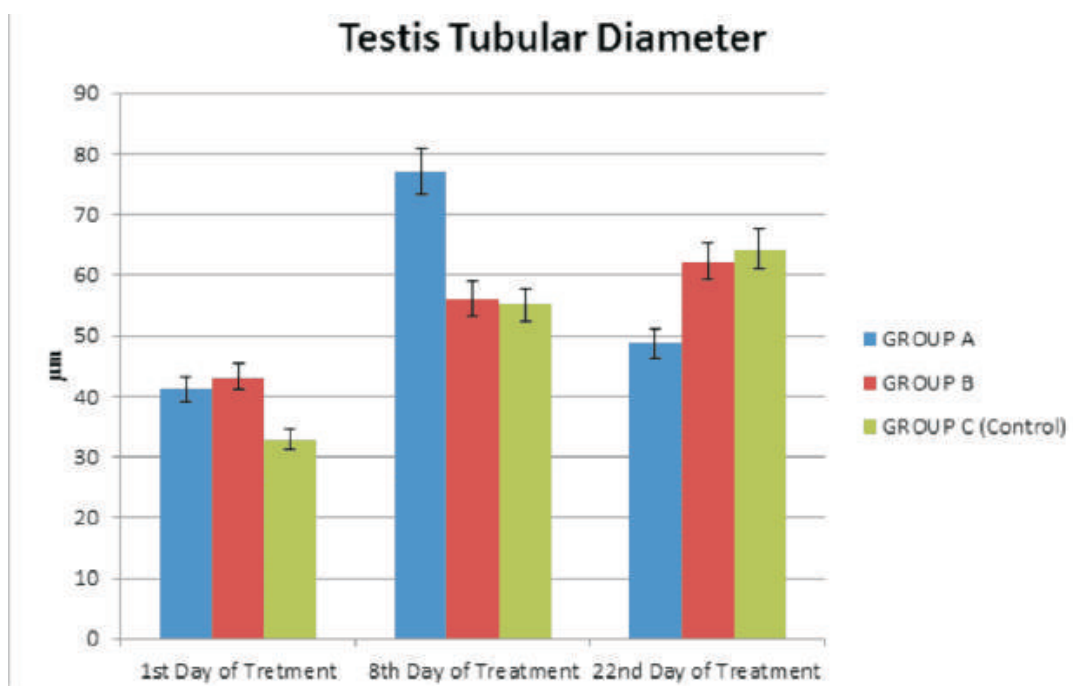

Figure 6: Bar chart comparing the mean differences in the seminiferous tubular diameter of the testis across the groups

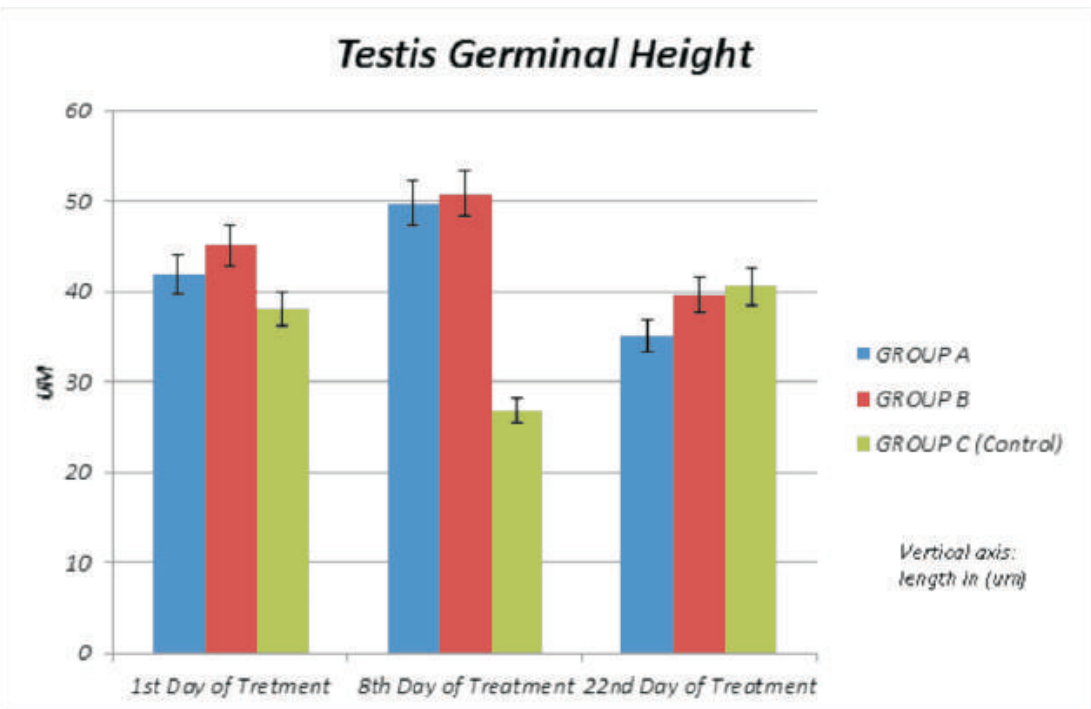

Figure 7: Bar chart comparing the mean differences in the seminiferous tubular germinal height of the testis across the groups

Histomorphometrical measurements of the testes revealed a non-significant increase ( $p$ $>0.05)$ in the seminiferous tubular diameter and germinal epithelial height of the testes across the three (3) groups for the three post-treatment. 


\section{Oyeyemi, Adedeji and Bankole}

Table 4: Mean values of weight of animal in the control and test groups

\begin{tabular}{|c|c|c|c|c|c|}
\hline \multirow[b]{2}{*}{ Days of sacrifice } & \multicolumn{3}{|c|}{ GROUP } & \multirow[b]{2}{*}{$\mathbf{F}$} & \multirow[b]{2}{*}{ P-Value } \\
\hline & A (50mg/kg) & B (100mg/kg) & $\mathrm{C}$ (control) & & \\
\hline $\begin{array}{l}\text { Acclimatization } \\
\text { period }\end{array}$ & $130.37 \pm 1.11^{\mathrm{a}}$ & $113.81 \pm 1.71^{\mathrm{b}}$ & $98.27 \pm 0.93^{\mathrm{abc}}$ & 153.8 & $0.00 *$ \\
\hline 1st Day post-treatment & $126.00 \pm 1.58^{\mathrm{a}}$ & $104.53 \pm 2.32^{\mathrm{b}}$ & $95.67 \pm 1.83^{\mathrm{abc}}$ & 65.02 & $0.00 *$ \\
\hline 8th Day post-treatment & $148.40 \pm 3.28^{\mathrm{a}}$ & $124.40 \pm 4.70^{\mathrm{b}}$ & $113.40 \pm 3.40^{\mathrm{abc}}$ & 21.64 & $0.00^{*}$ \\
\hline $22^{\text {nd }}$ Day post treatment & $159.60 \pm 4.26^{\mathrm{a}}$ & $133.20 \pm 4.26^{\mathrm{b}}$ & $116.80 \pm 5.08^{\mathrm{abc}}$ & 6.836 & $0.010^{*}$ \\
\hline
\end{tabular}

The batch of treatment groups from day 1 post-treatment had the least value of mean weight group A (126 mg), group B (104 mg) when compared to other groups. However, this increased significantly in the $8^{\text {th }}$ day post-treatment batch, with group A (148.40mg) and group B (124.40 mg).

The third batch of treatment group (day 22 post-treatment) had the highest mean body weight values across the groups. Within the groups at day 22 post-treatment, group A $(156.60 \pm 4.26)$ had the highest value followed by group B $(133.20 \pm 4.26)$. A statistically significant difference $(p<0.05)$ was observed in the mean body weight when compared to the control group $\mathrm{C}$

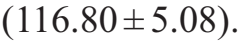

The three batches of treatment groups were observed to show a progressive increase in mean body weight across the groups.

\section{Discussion}

Results of the sperm motility for both treatments, groups A and B were lower than the sperm motility of the control group for the day-1 post-treatment, although the percentage improved gradually by the 8 th and 22nd-day post-treatments. This corroborates the findings of Oyeyemi et al. (2008) in which the spermatozoa motility of rats treated with the aqueous extract of Telfaria occidentalis leaves at $500 \mathrm{mg}$ and $1000 \mathrm{mg} / \mathrm{kg}$ for 14 days were lower ( $\mathrm{p}>$ $0.05)$ than the control group. The results obtained in the treatment groups at day 1 post-treatment in this study ( $22 \%$ motility) also agrees with the results of Kolawole et al. (2014) where $200 \mathrm{mg} / \mathrm{kg}$ of the methanolic extract of the rind of Citrullus lanatus fruit was administered for 35 days to albino rats. However, he reported a nonsignificant $(\mathrm{p}>0.05)$ increase in the motility of the treatment groups compared to other groups. The percentage livability from this study further validates the study of Oyeyemi et al. (2015) where there was no statistically significant difference $(\mathrm{p}>0.05)$ in the percentage livability among the various groups treated with the Saponin extract of Vernonia amygdalina del. Asteraeceae in male albino rats (Wistar strain). Furthermore, the result of the percentage abnormalities of sperm cells was significant in day 8 post-treatment. The defects are mainly of the tail, this might connote a spindle-related derangement in the germinal cell by the introduction of the Amaranthus hybridus extract. Those values are within the normal range. This supports the findings of Barrio et al. $(2010)$ who noted a significant increase $(\mathrm{p}<0.05)$ in morphological changes, rearrangement of the cytoskeleton and inhibited cell adhesion properties of protein isolates from an Amaranthus species, (A. mantegazzianus) which happens to be the protein exhibiting potential anti-tumour properties when fed to rats. Haematology revealed no statistically significant $(p>0.05)$ in the haemogram of the Wistar rats in the different doses at days $1,8 \& 22$. This suggests that the crude extract of Amaranthus hybridus does not have any deleterious effect on the blood picture of 
Wistar rats. This agrees with the submission of Kuffnor et al. (2013) that examined the effect of hydro-ethanolic extract of Amaranthus spinosus in rats. Kuffnor et al. (2013) observed that the vegetable had no lethal effect at $240 \mathrm{mg} / \mathrm{kg}$ dose on the blood of rat making it safe for use.

The testicular and epididymal histology revealed numerous seminiferous tubules packed full of viable spermatogenic cells in the testis and there were no visible lesions in the epithelium of the cauda epididymis. The cytoarchitecture of both the testis and the epididymis revealed no visible lesions. Histomorphometric studies of the testis and cauda epididymis revealed an increase in the germinal height and luminal diameter of the epididymis on the administration of the crude extract of Amaranthus hybridus but the increase was not significant ( $p>0.05)$. It might be possible that prolonged use of the extract can cause an increase in the functional capacity of the epididymal lining, which includes stabilization, maturation and transportation. The observation from this study on the weight of the rats shows that there was a treatment duration-dependent increase in body weight of the animals across the groups on days 1,8 and 22 post-treatment. If the administration of the extract continues, the animals might steadily gain a significant weight change. This also corroborates the study of Clemente and Desai (2011), which showed that oral administration of aqueous leaf extracts of Amaranthus tricolor prevented a decrease in body weight of treated diabetic rats and promoted improvement in haemoglobin levels.

In conclusion, based on the increase in the percentage of motility, livability and decrease in morphological abnormalities of the sperm cells at dose $1000 \mathrm{mh} / \mathrm{kg}$ for $22-$ day post-treatment, the Amaranthus hybridus aqueous extract has a potentiating effect on fertility capacity of male Wistar rats

\section{References}

Akubugwo, A., Sena, L. P., VanderJagt, D. J., Rivera, C., Tsin, A.T., Muhammadu, I, Mahammadu, O., Milson, M., Pastosyn, A., Glew, R. H. 2007. Analysis of Nutritional Components of eight famine foods of the Republic of Niger. Plant Foods Hum. Nutr. 52: $17-30$.

Barrio, D. A. and Anon, M. C. 2010. Potential centitumor properties of a protein isolate detained from the $\mathrm{s}$ e eds of A maranthus mantegazzianus Eur J. Nutr. 49 (2010), pp. 73-82.

Clemente, A. C. and Desdai, P. V. 2011. Evaluation of the Haemotological, Hypoglyces, Hypolipidemic and Antioxidant Properties of Amaranthus tricolor leaf extract in rat. Trop J. Pharm Res. 1092011 , pp. 595-602.

Frankel, E. N. 1993. In search of better methods to evaluate Natural Antioxidants and oxidative stability in food lipids. Trends Food Sci. Technol 4, 220-235

Ghosh, D., Mitra, P., Ghosh, T. and Mitra, P. K. 2016. Antipeptic ulcer activity of the leaves of Amaranthus spinosus L. in rats. Mintage J Pharm Medi Sci 2:3:5253.

Hassan, L. G. and Umar, K. J. 2006. Nutritional Value of Balsam Apple (Mormodica balsamina L) Leaves. Pakistan Journal Nutr, 5: 522-529

Hafez, E.S.E. 1970: Reproduction and Breeding Techniques for Laboratory Animals. Pg.28, 56, 57, 300-301

Hoffman, R. M. and Garewal, H. S. 1997. Antioxidants and Coronary Disease Prevention. In Antioxidants and Disease 
Prevention. (Harrinder S, Garewal MD, (eds). Pg 131 - 148 CRC Press.

Islam, M. Z., Awal, M. A. and Mostofa, M. 2009. Effect of Spinach against Arsenic toxicity in Rats. Bangl. J. Vet. Med (2009). 7(2):358-363.

Joshua, S. L., Pal, V. C., Kumark, L., Sahu, R. K. and Roy, A. 2010. Antitumor Activity of the EthanolicExtract of Amaranthus Spinosus Leaves against EAC bearing in Albino Mice. Der Pharmacia Lettre. 2:2:10-15

Kolawole, T. A., Dapper, D. V. and Ojeka, S. O. 2014. Ameliorating Effect of the Methanolic Extract of the Rind of Citrullus lanatus on lead acetateinduced toxicity on Semen Parameters and Reproductive Hormones of Male Albino Wistar Rats. Eur J. Med Plants 4 (9): $1125-1137$

Koffuor, G. A., Ainooson, G. K., Addoky, T. N.A., Amponsah, I. K., Afriyie, V. A., Tutu, R. 2013. Preliminary Pharmacological investigation of the Ischuretic Property and Safety of a hydro-ethanologic extract of Amarnathus Spinosis. (FAm: Amarnathaceae) Int. J. Basic. Clin. Pharmacol, 2 pp. 517-552.

Ladeji, O., Okoye, Z. S. and Ojobe, T. 1995. Chemical evaluation of the nutritive value of leaf of $\mathrm{f} 1 \mathrm{u} \mathrm{t}$ e d pumpkin (Telferia occidentalis). Food Chem. 53: 353-355.

Lieber, R. 1997. Storytelling: A new way to get close to your customer. Fortune 3 (Feb) 102-108.

Nguta, J. M., Mbaria, D. W., Gakuya, P. K., Gathumbi, S. and Kiama, G. 2010 Antimalarial herbal remedies of Msambweni Kenya. J. Ethnopharmacology 128, pp. 424452
Okafor, J. C. 1983. Horticultural Promising Indigenous Wild Plant Species of the Nigerian Forest Zone. Acta Hort. 123: 165-176.

Olukole, S. G. and Obayemi, T. E. 2010. Histomorphometry of the Testes and Epididymis in the Domesticated Adult African Great Cane Rat (Thryonomys Swinderianus). Int. $J$ ournal of Morphology 28(4): 1251-1254.

Oyeyemi, M. O. and Ubiogoro, 2005. Spermiogram and morphological characteristics testicular and epididymal spermatozoa of White Fulani Boar in Nigeria. Int J. of Morphology, 23(3):235-9.

Oyeyemi, M. O., Leigh, O. O., Ajala, O. O., Badejo, A. O. and Emikpe, B. O. 2008. The effects of the Aqueous extract of 'UGU' (Telfaria occidentalis) leaves on the testis and spermatozoa characteristics in the male albino rat (wistar strain). Folia veterinaria 52.2:102-105.

Oyeyemi, M. O. and Fayomi, A. P. 2011 Gonadosomatic Index and Spermatozoa Morphological characteristics of male wistar rats treated with graded concentration of aloe vera gel. Inter. Journ. Anim. Veteri. Adv. 13(2): 47-53.

Oyeyemi, M. O., Soetan, K. O. and Akinpelu, O. B. 2015. Sperm characteristics and Haemiogram of male albino rats (wistar strain) treated with Saponin extract from Veronia amygdalina del asteraeceae 110192 Journal of Cell and Animal Biology 9.3: 2630 .

Reece, W. O. 1997: Physiology of Domestic Animals $2^{\text {nd }}$ edition Lippincott Williams and Wilkins. Philadephia. Pp 124. 149:268-345

Susantiningsih, T. R., Ridwan, A. R., Prijanti, M., Sadikin, H. and 
Crude extract of Amaranthus hybridus and reproductive parameters of Wistar rats

Hans Freisleben 2012 . Schizonicidal effect of a combination of Amaranthus spinonsus L. and Andrographis panicutata. Burm. F./Nees extracts in Plasmodium berghei-infected mice. Medical Journal Indonesia, 21 pp. 66-70.

Turan, M., Kordali S., Zengin H., Dursun A., Sezen Y. 2003. Macro and Micro- Mineral content of some wild edible leaves consumed in Eastern Anatolia. Acta Agric. Scand., Sect. B, Plant Soil Sci. 53: 129-137.
Zemjanis, R. 1970 Diagnostic and Therapeutic Techniques in Animals Reproduction.. William and Wilkins Company, Baltimore, USA, P. 242.

Received: $20^{\text {th }}$ July, 2020

Accepted: $4^{\text {th }}$ October, 2020 